\title{
Form-Focused Instruction in Communicative Language Teaching: Implications for Grammar Textbooks
}

Derrick J. Millard

This article examines a number of adult ESL grammar textbooks via an authordesigned checklist to analyze how well they incorporate the findings from research in communicative language teaching (CLT) and in form-focused instruction (FFI). It concludes that although a few textbooks incorporate some of the research findings in CLT and FFI, they are not necessarily those chosen by the teaching institutions.

\section{The Need for New Grammar}

It has long been accepted by practitioners and academics alike that communicative language teaching (CLT) is the preferred way ESL should be taught (Savignon, 1991). Research in several CLT programs has, however, continually uncovered serious limitations in the exclusive CLT model. Studies done in the 1980s and 1990s showed that French immersion in Canada, one of the best examples of true CLT as it exists today (Krashen, 1985), consistently produced students who did not develop native-like abilities in written or oral production or sociolinguistic skills even after six or seven years of instruction (Genesse, 1987; Harley, 1991; Harley \& Swain, 1984; Lapkin, Swain, \& Cummins, 1983; Lyster, 1994; Swain, 1985; Swain \& Lapkin, 1982). Similarly, research in CLT-based intensive ESL programs in Quebec (Spada \& Lightbown, 1989) and New Brunswick (Lightbown, 1992) has also found that although the fluency of students in the CLT programs differs significantly from that of their counterparts in more traditional programs, there is often a lack of grammatical accuracy (Lightbown, 1991, 1992; Lightbown \& Spada, 1990). These findings suggest that some form of grammatical instruction needs to be included in CLT programs.

This grammatical instruction, known as form-focused instruction ${ }^{1}$ (FFI), was originally designed to be instruction "that overtly draws students' attention to linguistic elements as they arise incidentally in lessons whose overriding focus is on meaning or communication" (Long, 1991, pp. 45-46). Recently, however, some researchers have questioned this exclusively reactive approach to FFI and have suggested that more isolated proactive teaching is necessary for some students to learn some forms (see Spada, 1997 for a review). Further, the issue of how explicit the FFI needs to be to have learners notice the gap between their language production and that of native speakers 
is largely unclear (Schmidt, 1990). Research does suggest, however, that explicit teaching and/or feedback may be required to learn many, but not all, aspects of a second language (Spada, 1997). Regardless of which approach is favored, it is clear that the grammar teaching must not be done in isolation, but should be incorporated into CLT. This is necessary as research into both CLT and FFI suggests that learners need both communication to obtain high levels of fluency and form-oriented instruction to reduce errors (Long, 1990, 1991; Savignon; 1991; Spada, 1997).

\section{Issues in Grammar Textbooks}

Traditionally, authors and textbook publishers have designed ESL grammar textbooks to focus on examples and explanations of arbitrarily sequenced linguistic rules followed in turn by an application of those rules in disconnected drills, exercises, and / or sample sentences (Richards \& Rodgers, 1986; Stern, 1992). The textbook writers seemed to assume that explicit knowledge of a form would lead to a transfer of that knowledge to communicative ability. Research has consistently shown, however, that this is rarely the case (Howatt, 1984; Krashen, 1985; Richards \& Rodgers; Widdowson, 1979). It is thus necessary to apply CLT theories to grammar textbooks as well.

Because the core premise of CLT is that there must be a genuine purpose for language use where the overall emphasis is on the exchange of information and the negotiation of meaning (Breen \& Candlin, 1980; Howatt, 1984; Widdowson, 1979), grammar textbooks need to do more than teach grammatical forms. They also need to provide the students with a reason to talk (Chastain, 1987; Stern, 1992). This may be accomplished in numerous ways, but the activities must utilize meaningful contexts and stress pragmatic use of the linguistic forms that extend past the level of isolated sentences (Hadley Omaggio, 1993; Larsen-Freeman, 1995). This is important because, as Brown (1994) points out, language is not spoken at the sentence level, but at the discourse level where meanings are taken from "referents in both previous sentences and following sentences" (p. 235) and not from individual sentences in isolation. This contextualization has many levels, and as the levels increase, so does the communicative purpose (Chastain, 1987; Hadley Omaggio, 1993; Walz, 1989).

At the most basic level, grammar textbooks need to link sentences to each other through a common meaningful theme (Hadley Omaggio, 1993; Walz, 1989). Although this does not guarantee that the task is communicative, it is a necessary first step as it provides some sense of reality for the students (Walz). At a deeper level, contextualization of activities is done so that one sentence naturally flows from another. This provides texts that resemble natural speech. Although this deepens the contextualization, it "does not necessarily force the learner to make choices as true communication does" (Walz, p. 161). These choices, however, are the backbone of true communica- 
tion, for in authentic conversations there is rarely only one acceptable response in any situation (Chastain, 1987; Walz). Textbooks must, therefore, strive to reach the highest level of contextualization that forces students to make choices between alternatives. This necessitates longer activities that are open-ended and demand choices. If grammar textbooks do not attempt to incorporate any of these levels, their methodologies should be examined, and educators should question the appropriateness of using such textbooks.

Another area of concern when looking at grammar textbooks is that of sequencing. Research has consistently shown that proficiency in a language is not developed one linguistic item at a time (Long, 1991). Further, because it is unknown which forms are open to FFI and which are not (Harley, 1993), sequential instruction based on linguistic forms contradicts the findings of research done in both CLT and FFI. It is, therefore, illogical to structure textbooks in such a manner. CLT and FFI research has shown that textbooks need to have some form of explicit metalinguistic teaching that maintains a communicative focus that interests learners while allowing teachers to sequence their classes as they deem appropriate. The purpose of this study was to discover how well common present-day grammar textbooks have incorporated these findings.

\section{Method}

Lists of grammar textbooks (see Appendix A) used in intensive ESL classes were obtained from three of the major ESL providers in Edmonton, Alberta, Canada. The institutions were chosen because of the similarity in their sizes and the number of classes that they offer. The chosen institutions provide an average of 4.7 hours of instruction per day over an average of 13.7 weeks for a total overall average of 325 hours of instruction to both international students and Canadian residents. Class sizes at these institutions range from 7 to 19 students with an average of 16.6 students per class. The lists of the grammar textbooks were obtained from teachers at the three institutions during staff meetings and through personal contact. Only textbooks whose primary purpose was grammar instruction for adult learners were used in this study.

The 13 selected textbooks were then analyzed using a checklist (see Appendix B) that I designed to assess how well they integrated focus on grammatical forms in CLT-based classrooms. The checklist was designed to measure four categories: context, activities, explanations, and practicality. Each of these categories encompasses three statements in the textbook checklist. These statements address similar elements and/or concerns from the research findings. Although the three statements in each category do not measure exactly the same aspect of the feature, they do measure different elements of their respective category labels. 
The first three statements deal with contextualization or the lack of it. As highlighted above, contextualization is a necessary first step in developing a communicative purpose. These three statements allow for the assessment of the three different contextualization levels outlined above. Statements 4-6 were designed to analyze the communicative focus of the activities: specifically, how well the textbooks allow negotiation of information while maintaining students' interest, both of which CLT research has shown to be necessary. Statements 7-9 were based on the findings in FFI research that suggest that students need explicit grammatical explanations that are levelappropriate, while stressing not only form, but also function and pragmatic use. The last three statements were designed not on research, but on issues that have a direct impact on teaching and the ease of implementation. It was felt that regardless of the theoretical validity of a textbook, if it were not teacher-friendly, it would not be effective. The textbooks were rated by one rater on one individual grammatical form-the present progressive aspect, in addition to a holistic impression of the entire textbook.

The textbooks were ranked on a scale ranging from 0 (never present) to 5 (always present). The marks were assigned using the following criteria: 5 (always present): the feature being looked at was present in every chapter and activity; 4 (usually present): the feature was present in more than $80 \%$ of the chapters and activities; 3 (often present): the feature was present in more than $60 \%$ of the chapters and activities; 2 (sometimes present): the feature was present in more than $30 \%$ of the chapters and activities; 1 (rarely present): the feature was present in fewer than $30 \%$ of the chapters and activities; 0 (never present): the feature was not present in any of the chapters or activities.

Each textbook was assessed on all 12 statements in the checklist in Appendix B, with three statements in each of the four categories. For each textbook, category scores, total score, and mean category score were calculated. Total and mean scores were also calculated for all 13 textbooks. These results are presented in Table 1.

Although I analyzed the textbooks using a checklist that I designed, issues of reliability and validity were addressed. Interrater reliability was ensured by an assessment of the textbooks on two separate occasions more than two weeks apart. When there was more than a one-point discrepancy, the textbooks were rated a third time. I believed that by doing this a more accurate assessment of the textbooks could be assured.

Construct validity was addressed through frequent consultation between myself and an expert in the field (research advisor; see acknowledgements). Systematic revision of the assessment method-namely, the checklist-was carried out. The checklist was designed largely based on research findings in both CLT and FFI. Only in one category, that of practicality, did I base the 
Table 1

Checklist Findings in Rank Order of Category Means

\begin{tabular}{lcccccc}
\hline Author(s) & $\begin{array}{c}\text { Context } \\
/ 15\end{array}$ & $\begin{array}{c}\text { Activities } \\
/ 15\end{array}$ & $\begin{array}{c}\text { Explanations } \\
/ 15\end{array}$ & $\begin{array}{c}\text { Practicality } \\
/ 15\end{array}$ & $\begin{array}{c}\text { Total } \\
/ 60\end{array}$ & $\begin{array}{c}\text { Mean } \\
/ 15\end{array}$ \\
\hline Riggenbach \& Samuda (1997) & 15 & 13 & 15 & 13 & 56 & 14 \\
Frodesen \& Eyring (1997) & 12 & 10 & 15 & 13 & 50 & 12.5 \\
Schoenberg(2000) & 12 & 9 & 13 & 13 & 47 & 11.75 \\
Elbaum \& Conway (1998) & 10 & 8 & 15 & 8 & 41 & 10.25 \\
Wajnryb (1990) & 15 & 11 & 0 & 10 & 36 & 9 \\
Foley \& Neblett (1997) & 11 & 10 & 7 & 8 & 36 & 9 \\
Azar (1992) & 3 & 9 & 10 & 12 & 34 & 8.5 \\
Dean (1993) & 6 & 7 & 15 & 6 & 33 & 8.25 \\
Azar (1999) & 4 & 7 & 8 & 12 & 31 & 7.75 \\
Berish et al. (1996) & 4 & 6 & 9 & 4 & 23 & 5.75 \\
Murphy (1989) & 2 & 4 & 9 & 6 & 21 & 5.25 \\
Murphy (1993) & 2 & 4 & 9 & 6 & 21 & 5.25 \\
Emery et al. (1994) & 0 & 1 & 8 & 3 & 12 & 3 \\
\hline Total & 96 & 99 & 133 & 114 & 441 & 110.25 \\
Mean & 7.4 & 7.6 & 10.2 & 8.8 & 34 & 8.5 \\
\hline
\end{tabular}

checklist on my own personal experience in the field. In retrospect, another experienced teacher could have been consulted.

\section{Results}

As shown in Table 1, the results show relative consistency in textbook and category variation. Textbooks such as those of Riggenbach and Samuda (1997), Frodesen and Eyring (1997), and Schoenberg (2000) show relatively high patterns of consistency across all four categories resulting in high category means. Of these three textbooks, only Schoenberg had a score below 10 in any category, whereas Riggenbach and Samuda's category scores never went below 13 out of 15 . This consistency led to overall scores ranging from 56 out of 60 for Riggenbach and Samuda to 47 out of 60 for Schoenberg. These high category scores, of course, then led to high category mean scores, ranging from 14 (Riggenbach \& Samuda), to 12.5 (Frodesen \& Eyring), to 11.75 (Schoenberg) out of 15.

In contrast, the textbook of Emery, Kierzek, and Lindblom (1994), consistently scored low. In context Emery et al. obtained a score of 0 out of 15, in activities 1 out of 15, and in practicality 3 out of 15 . Even in the category of explanations where Emery et al. achieved a mean score of 8 , they did not equal the mean of 8.2 across all textbooks in this category. Here the other 
lower-end textbooks did relatively well. On analysis it becomes clear that the lower-mean textbooks were designed to be explicit in their grammatical teachings, but little effort was put into contextualizing the activities or making them communicative in any form. Similar patterns, although to a lesser degree, can be found in the textbooks in the middle domain of Table 1 as well. These textbooks, such as Azar $(1992,1999)$, similarly lack contextualization or communicative focus, but are once again strong in explanations. What often buoys these textbooks, however, is their practicality. The supplemental resources available for Azar $(1992,1999)$ are substantial, and it is thus not surprising that, regardless of their rankings on the checklist, only these two textbooks were reported as being used by all three institutions.

It should be noted, however, that there was one glaring exception to the pattern stated above. Wajnryb (1990) is the only textbook that obtained a middle ranking, not because of its activities, but because of its lack of explicit explanations. On further examination it was clear that this textbook was designed not as a student book, but rather as a supplemental book for teachers. Its focus is not on the initial presentation of grammatical forms, but rather on practice and discovery of them through communication. This, then, accounts for its low explanation score. It is surprising, though, that despite a score of 0 in this area, Wajnryb is still in the top half of all the textbooks.

\section{Discussion}

The variation in textbook ratings reflects the reality of the materials that are available and used by ESL teachers. The results in Table 1 suggest that although the practical issues of explanation and implementation have often been dealt with, those issues that concern the theoretical aspects of contextualization and activity variation are often superficially addressed. The different approaches to contextualization and activities become clear when one examines the textbooks. There was a marked difference between low-mean and middle-mean textbooks and then again between middle-mean and highmean textbooks in how the present progressive aspect was presented. The textbooks at the higher end of the line not only provide a wide range of communicative-based activities for practice, but they also contextualize it. This was evident in the first activities in both Riggenbach and Samuda (1997) and Schoenberg (2000). The textbooks either provide a reading (Riggenbach \& Samuda) or a dialogue (Schoenberg) that embeds the grammatical form in a context. Schoenberg goes even further by highlighting the present progressive aspect for the student in the body of the text. This contextualization is found in all the activities for the present progressive aspect for both Riggenbach and Samuda and Schoenberg, and indeed throughout most of the activities in both textbooks. In contrast, the low-mean textbooks such as those by Murphy $(1989,1993)$ provide few contextualized activities. Murphy provides only one dialogue for the present progressive for the two textbooks. 
The rest of the five activities on the present progressive in the two textbooks are disconnected from each other, and all the students need do is fill in the blanks with the words provided.

In the middle-mean textbooks, contextualization in dialogues is present, but this contextualization is brief and rarely goes beyond two sentences before another two- to three-sentence dialogue with no connection to the previous one is introduced. These longer dialogues and readings, however, provide the communicative focus and need in textbooks. Without the longer dialogues, students learn only short fragments of conversations and are never shown when or how to use the grammatical rule in a wider context.

These results suggest that textbook writers and publishers are only beginning to bridge the gap between past sentence-level grammar teaching to form-focused instruction based on current research findings in second language acquisition. The present study found only three out of 13 textbooks with high ratings for form-focused instruction for communicative language teaching. However, these high-rated textbooks are not those consistently selected by language institutions.

\section{Implications and Limitations}

The results from this study suggest that textbook writers and publishers need to address more fully how to integrate grammar instruction in CLT. According to the checklist findings, not enough is being done to contextualize the grammar at more than the sentence or text level, and the emphasis on function and pragmatic usage is not evident enough. Until new textbooks address these issues, teachers are in the unenviable position of having to modify any grammar textbook they use.

The blame, however, cannot be placed squarely on textbook writers and publishers. Some newer textbooks have approached language teaching in a way that is consistent with research findings in FFI and CLT. However, these materials are not yet widely adopted by the various adult ESL programs.

It is important to note that this study examined only those textbooks that were currently being used by three of the major ESL providers in the city of Edmonton. It did not examine all the grammar textbooks that are currently on the market. It is possible that textbooks that more fully incorporate FFI and CLT research findings do exist, but if so, they were beyond the scope of this study. Further, I rated the textbooks alone with a checklist of my own design, and this may have introduced bias into the procedure. Future studies need to address issues of validity and reliability. Nevertheless, this small study opens the door to important and greatly needed knowledge of our most current teaching practice. 


\section{Note}

${ }^{1}$ Similar concerns have been addressed under the rubrics of the noticing hypothesis (Rutherford \& Sharwood Smith, 1985, 1988; Sharwood Smith, 1981; Schmidt, 1990), focus on form (Long, 1991), input enhancement (Sharwood Smith, 1991), analytic-experimental (Stern, 1992), and negative evidence (White, 1991).

\section{Acknowledgments}

This article is based on a portion of my master's project. I gratefully acknowledge my supervisor Leila Ranta for her guidance every step of the way. I would also like to thank the editors and the three anonymous reviewers of TESL Canada Journal for their wonderful and informative feedback.

\section{The Author}

Derrick Millard (MEd, University of Alberta) has taught for five years in Japan and Canada. He is presently teaching at Fujairah Women's College, Higher Colleges of Technology, United Arab Emirates. His interests lie in grammar education and the need for contextualization. E-mail inquires can be sent to derrick.millard@hct.ac.ae.

\section{References}

Azar, B.S. (1992). Fundamentals of English grammar (2nd ed.). Englewood Cliffs, NJ: Prentice-Hall.

Azar, B.S. (1999). Understanding and using English grammar (3rd ed.). Upper Saddle River, NJ: Prentice-Hall.

Berish, L., Thibaudeau, S., \& Wilson, M. (1996). Grammar connections 3. Scarborough, ON: Prentice Hall Canada.

Breen, M.P., \& Candlin, C.N. (1980). The essential of communicative curriculum in language teaching. Applied Linguistics, 1, 89-112.

Brown, H.D. (1994). Teaching by principles: An interactive approach to language pedagogy. Englewood Cliffs, NJ: Prentice-Hall.

Chastain, K. (1987). Examining the role of grammar explanation, drills, and exercises in the development of communication skills. Hispania, 70, 160-166.

Dean, M. (1993). English grammar lessons. Oxford: Oxford University Press.

Elbaum, S.N., \& Conway, P.M. (1998). Grammar in context 2: Canadian edition. Scarborough, ON: TTP Nelson.

Emery, D.W., Kierzek, J.M., \& Lindblom, P. (1994). English fundamentals (10th ed.). New York: Macmillan.

Foley, B.H., \& Neblett, E.R. (1997). The new grammar in action 1. Boston, MA: Heinle \& Heinle. Frodesen, J., \& Eyring, J. (1997). Grammar dimensions 4 (2nd ed.) (D. Larsen-Freeman, Ed.). Boston, MA: Heinle \& Heinle.

Genesse, F. (1987). Learning through two languages: Studies in immersion and bilingual education. Cambridge, MA: Newbury House.

Hadley Omaggio, A.C. (1993). Teaching language in context (2nd ed.). Boston, MA: Heinle \& Heinle.

Harley, B. (1991). Directions in immersion research. Journal of Multilingual and Multicultural Matters, 12(1), 9-19.

Harley, B. (1993). Instruction strategies and SLA in early French immersion. Studies in Second Language Acquisition, 15, 245-259. 
Harley, B., \& Swain, M. (1984). The interlanguage of immersion students and its implications on second language teaching. In A. Davies, C. Criper, \& A.P.R. Howatt (Eds.), Interlanguage (pp. 291-311). Edinburgh, UK: Edinburgh University Press.

Howatt, A.P.R. (1984). A history of English language teaching. Oxford: Oxford University Press.

Krashen, S.D. (1985). Inquiries and insights. Hayward, CA: Alemany Press.

Lapkin, S., Swain, M., \& Cummins, J. (1983). Final report on the development of French language evaluation units for Saskatchewan. Toronto, ON: OISE Press.

Larsen-Freeman, D. (1995). On the teaching and learning of grammar: Challenging the myths. In F.R. Eckman, D. Highland, P.W. Lee, J. Milcham, \& R.R. Weber (Eds.), Second language acquisition theory and pedagogy (pp. 131-150). Mahwah, NJ: Erlbaum.

Lightbown, P.M. (1991). What have we here? Some observations on L.2 learning. In R. Phillipson, E. Kellerman, L. Selinker, M. Sharwood Smith, \& M. Swain (Eds.), Foreign language pedagogy research: A commemorative volume for Claus Faerch (pp. 197-212). Clevedon, UK: Multilingual Matters.

Lightbown, P.M. (1992). Can they do it themselves? A comprehension-based ESL course for young children. In R. Courchêne, J. St. John, C. Thérien, \& J. Glidden (Eds.),

Comprehension-based language teaching: Current trends (pp. 353-370). Ottawa: University of Ottawa Press.

Lightbown, P.M., \& Spada, N. (1990). Focus-on-form and corrective feedback in communicative language teaching: Effects on second language learning. Studies in Second Language Acquisition, 12, 429-448.

Long, M.H. (1990). The least a second language acquisition theory needs to explain. TESOL Quarterly, 24, 649-666.

Long, M.H. (1991). A design feature in language teaching methodology. In K. de Bot, R.B. Ginsberg, \& C. Kramsch (Eds.), Foreign language research in cross-cultural perspective (pp. 39-52). Amsterdam: John Benjamins.

Lyster, R. (1994). The effects of functional-analytic teaching on aspects of French immersion students' sociolinguistic competence. Applied Linguistics, 15, 263-287.

Murphy, R. (1989). Grammar in use. Cambridge: Cambridge University Press.

Murphy, R. (1993). Basic grammar in use. Cambridge: Cambridge University Press.

Richards, J.C., \& Rodgers, T.S. (1986). Approaches and methods in language teaching. Cambridge: Cambridge University Press.

Riggenbach, H., \& Samuda, V. (1997). Grammar dimensions 2 (2nd ed.) (D. Larsen-Freeman, Ed.). Boston, MA: Heinle \& Heinle.

Rutherford, W., \& Sharwood Smith, M. (1985). Consciousness-raising and universal grammar. Applied Linguistics, 6(3), 274-282.

Rutherford, W., \& Sharwood Smith, M. (1988). Consciousness raising and universal grammar. In W. Rutherford \& M. Sharwood Smith (Eds.), Grammar and second language teaching (pp. 107-116). New York: Newbury House.

Savignon, S.J. (1991). Communicative language teaching: State of the art. TESOL Quarterly, 25, 261-277.

Schmidt, R.W. (1990). The role of consciousness in second language learning. Applied Linguistics, 11, 129-158.

Schoenberg, I.E. (2000). Focus on grammar: A basic course for reference and practice (2nd ed.). Reading, MA: Addison-Wesley.

Sharwood Smith, M.A. (1981). Consciousness-raising and the second language learner. Applied Linguistics, 11, 159-168.

Sharwood Smith, M.A. (1991). Speaking to many minds: On the relevance of different types of language information for the L2 learner. Second Language Research, 7, 118-132.

Spada, N. (1997). Form-focused instruction and second language acquisition: A review of classroom and laboratory research. Language Teaching, 30, 73-87. 
Spada, N., \& Lightbown, P.M. (1989). Intensive ESL programmes in Quebec primary schools. TESL Canada Journal, 7(1), 11-32.

Stern, H.H. (1992). Issues and options in language teaching. Oxford: Oxford University Press.

Swain, M. (1985). Communicative competence: Some roles of comprehensible input and comprehensible output in its development. In S. Gass \& C. Madden (Eds.), Input in second language acquisition (pp. 235-256). Rowley, MA: Newbury.

Swain, M., \& Lapkin, S. (1982). Evaluating bilingual education: A Canadian case study. Clevedon, UK: Multilingual Matters.

Wajnryb, R. (1990). Grammar dictation. Oxford: Oxford University Press.

Walz, J. (1989). Context and contextualized language practice in foreign language teaching. Modern Language Journal, 73, 160-168.

White, L. (1991). Adverb placement in second language acquisition: Some effects of positive and negative evidence in the classroom. Second Language Research, 7, 133-161.

Widdowson, H.G. (1979). The teaching of English as communication. In C. Brumfit \& K. Johnson (Eds.), The communicative approach to language teaching (pp. 117-121). Oxford: Oxford University Press.

\section{Appendix $A$}

\section{Textbooks}

\begin{tabular}{|c|c|c|}
\hline Author(s) & Title & $\begin{array}{l}\text { Level (indicated } \\
\text { by publisher) }\end{array}$ \\
\hline Azar (1992) & Fundamentals of English Grammar & Intermediate \\
\hline Azar (1999) & Understanding and Using English Grammar & Intermediate-Advanced \\
\hline Berish et al. (1996) & Grammar Connections 3 & Advanced \\
\hline Dean (1993) & English Grammar Lessons & Upper Intermediate \\
\hline Elbaum \& Conway (1998) & Grammar in Context 2: Canadian Edition & Intermediate \\
\hline Emery et al. (1994) & English Fundamentals & Not Indicated \\
\hline Foley \& Neblett (1997) & The New Grammar in Action 1 & High Beginner \\
\hline Frodesen \& Eyring (1997) & Grammar Dimensions 4 & Advanced \\
\hline Murphy (1989) & Grammar in Use & Intermediate \\
\hline Murphy (1993) & Basic Grammar in Use & Beginner \\
\hline Riggenbach \& Samuda (1997) & Grammar Dimensions 2 & Low Intermediate \\
\hline Schoenberg $(2000)$ & Focus on Grammar & Beginner \\
\hline Wajnryb (1990) & GrammarDictation & Beginner to Advanced \\
\hline
\end{tabular}




\section{Appendix B: Textbook Checklist}

1. Materials are contextualized at the sentence level. (i.e., sentences are linked by a thematic concept)

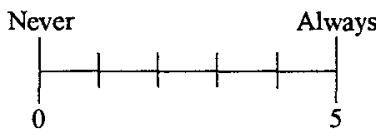

2. Materials are contextualized at the text level. (i.e., sentences flow from each other)

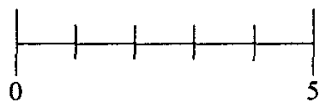

3. Materials are contextualized at the task level. (i.e., communication is necessary)

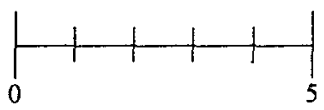

4. Activities are open-ended.

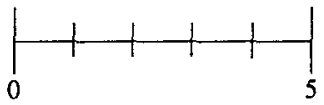

5. Activities vary from unit to unit.

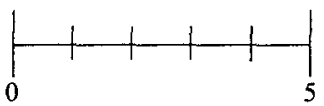

6. Activities emphasize meaning and function over form.

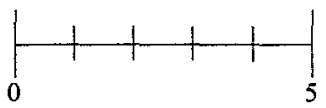

7. Metalinguistic terminology is used.

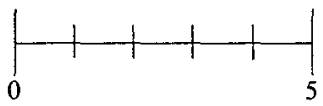

8. Simplified explanations are used.

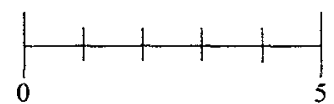

9. Materials explain/give examples of the form, function, and sociolinguistic use of the form.

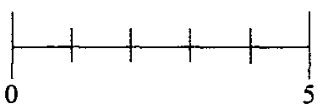

10. Non-sequential progression is assumed.

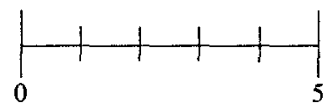

11. Supplemental materials are available.

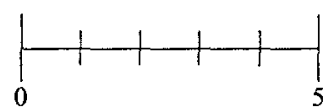

12. Teaching suggestions are provided.

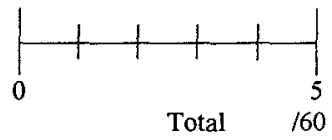

